\title{
MEMÓRIAS DE FAMÍLIA: A COSTURA DE VESTUÁRIO E OUTROS OFÍCIOS EM CARUARU-PE.
}

\author{
Wecisley Ribeiro do Espírito Santo ${ }^{1}$
}

\section{Introdução}

Esta comunicação constitui um relato preliminar do trabalho de campo que tenho realizado em uma localidade de Caruaru, Pernambuco, Brasil, majoritariamente habitada por costureiras e costureiros de vestuário, o bairro do Salgado. Com efeito, este distrito - como de resto, todo o município, juntamente com outras cidades contíguas, tais como Santa Cruz do Capibaribe e Toritama - é parte constitutiva de um aglomerado mais amplo de confecções e fabricos ${ }^{2}$ de vestuário, por vezes chamado de polo de confecções do Agreste de Pernambuco, polo da sulanca ${ }^{3}$ ou ainda Arranjo Produtivo

\footnotetext{
${ }^{1}$ Universidade Federal do Rio de Janeiro, Brasil.

${ }^{2}$ Fabrico, no contexto do Agreste de Pernambuco, constitui um termo polissêmico cujo significado preciso não pode ser definido senão contextualmente. Por vezes ele diz respeito a unidades produtivas de vestuário de médio ou pequeno porte detentoras de uma marca. Esta acepção aparece, sobretudo relacionalmente, em contraposição às facções - unidades domésticas de produção, frequentemente informais, que procedem à montagem (total ou parcial) terceirizada de uma peça de vestuário - sendo o fabrico, neste caso específico, a firma formal que terceiriza a produção para a façção, cabendo ao primeiro apenas a aplicação da marca. Há, porém, uma conotação, por assim dizer, mais tradicional referida ao caráter artesanal da costura em domicílio. Neste caso, os fabricos podem ser unidades domésticas de produção autônomas; isto é, que não terceirizam a produção, a família sendo responsável por todas as etapas do processo produtivo e, por vezes também, da comercialização na feira da sulanca. Eventualmente, por fim, fabrico pode assumir um significado mais abrangente - abarcando até mesmo grandes fábricas de vestuário. Há também uma oposição entre fabrico e confecção - o primeiro termo marcando o caráter artesanal, tradicional, familiar, da costura de vestuário e relacionado á comercialização na feira da sulanca -; o segundo, por seu turno, referente à produção moderna dos novos empreendedores, ex-sulanqueiros, que vendem seus produtos em grandes lojas ou em pólos comerciais como o Santa Cruz Moda Center, em Santa Cruz do Capibaribe. Esta oposição binária é bastante expressiva de posições políticas conflitantes, sobretudo no que se refere aos rumos que o pólo de confecções do agreste deve seguir - incluindo aqui uma ameaça recente de privatização da feira da sulanca (convertendo-a em uma espécie de shopping center nos moldes do Santa Cruz Moda Center, de Santa Cruz do Capibaribe, onde a privatização da feira constitui processo consumado), contra a qual os sulanqueiros têm lutado bravamente nos últimos anos. A oposição entre trabalho formal e informal também expressa parcialmente cada um destes respectivos pólos.

${ }^{3}$ Sulanca, no âmbito do setor de produção e comercialização de peças de vestuário da região, constitui um termo de significado mais ou menos abrangente segundo o contexto de enunciação. Referindo-se inicialmente ao tecido que serviu, por algum tempo, como matéria-prima principal da produção de vestuário, ele passou a designar também o produto acabado, o local onde as peças são comercializadas (feira da sulanca), como também o conjunto das unidades produtivas da região (pólo da sulanca). É preciso também notar que outros termos foram gradativamente derivando do primeiro, tal como é o caso de sulanqueiro, que se refere simultaneamente ao dono de um fabrico - ao qual se contrapõe o dono de confecção, que não é sulanqueiro, mas empreendedor -; a um costureiro de vestuário - seja ele empregado de outrem ou produtor por conta própria - a um comerciante da sulanca na feira; e a um sacoleiro, que vem muito amiúde de outros estados do país adquirir as peças de vestuário para revendê-las em sua própria região. A versão mais comumente formulada pela população local para dar conta das origens da palavra é uma contração de sul (referido, mormente á região Sudeste do país, supostamente o local de onde vieram os primeiros retalhos que serviram de base para a costura de roupas) e helanca (tecido de que os retalhos eram constituídos). Assim, tem-se sul+helanca= sulanca. Outra explicação
} 
Local de confecções do Agreste. Esta última expressão parece não ter sustentação empírica já que, na prática, testemunhamos uma infinidade de arranjos produtivos locais - com minúsculas - cujas formas de ordenação variam grandemente e expressam, no mais das vezes, uma organização familiar e pela vizinhança do trabalho nos fabricos. Conceder-se-á, na narrativa, largo espaço às memórias e depoimentos da família que me hospedou considerados assim como "casos privilegiados" para o entendimento do ofício e dos sentidos a ele atribuídos, no local.

De fato, toda a admirável família de dona Eugênia tem contribuído de maneira determinante para minha compreensão precária das relações e dos aspectos culturais dos trabalhadores do bairro. É a partir das interpretações que este grupo familiar tem me apresentado acerca de seu universo social que elaboro, por assim dizer, este relato de segunda mão. E, no entanto, os erros contidos neste texto são evidentemente de minha responsabilidade.

Dona Eugênia criou seus quatro filhos trabalhando na costura de peças de vestuário as quais, por vezes, ela mesma vendia na feira de Caruaru. Por seu turno, seu José Mário - o esposo de dona Eugênia - forneceu sua contribuição para a criação dos filhos com seu trabalho com mármore. Grande parte de minhas anotações de campo as redigi apoiando meu caderno sobre uma mesa cuja superfície é uma plataforma de mármore e cuja base é constituída por uma antiga máquina de costura movida a pedal. Minha mesa é, pois, além de mesa mesmo, um objeto simbólico do casamento entre o marmorista José Mário e a costureira Eugênia ${ }^{4}$. Não obstante, seria puro reducionismo de minha parte definir seu José Mário como mero marmorista (conquanto, na condição de marmorista, ele seja considerado o melhor de seu ofício - o que lhe valeu o apelido de o "Pelé do mármore", como todos em Caruaru o conhecem) e dona Eugênia como apenas costureira (ainda que este ofício tenha lhe possibilitado a proeza de criar quatro

variante é aquela segundo a qual o termo seria uma simplificação da expressão sucata de helanca, referindo-se à antiga acepção pejorativa do termo, hoje bastante enfraquecida.

${ }^{4}$ Poder-se-ia também pensar neste objeto como um "lugar de memória" (Nora, 1989); de uma "memória coletiva" (Halbwachs, 1990) materializada, que remete a uma ocasião da vida de dona Eugênia possivelmente o período de costura doméstica artesanal do qual este artigo trata -, bem como a uma fase da biografia de seu José Mário. Ambas, por sinal, quase coetâneas. Esta mesa improvisada a partir de materiais de trabalho já, por assim dizer, aposentados constitui também a expressão de uma "memória incorporada" (Shaw, 2002) nas práticas de reaproveitamento radical de materiais disponíveis que são bastante difundidas entre os sulanqueiros e que remetem a uma tradição artesanal destes trabalhadores. Tradição, por sinal, bem expressa na história, nos múltiplos sentidos e nas origens possíveis do termo sulanca, que se refere ao fenômeno do reaproveitamento de retalhos - o refugo da produção de tecelagens e grandes empresas de vestuário - na criação de alternativas para a produção das condições materiais de existência de milhares (quem sabe até chegando à casa dos milhões) de trabalhadores agrestinos. 
filhos). Muito mais do que isso são ambos "bricoleurs" (Lévi-Strauss, 1976; Weber, $\left.1989^{5}\right)$ - do que a mesa que mencionei constitui apenas a expressão menor.

O primeiro membro da família que conheci, em 2009, foi Eugênio, mais velho dos quatro irmãos. Naquela primeira oportunidade eu não pude senão entrever muito indefinidamente o alcance das contribuições que Eugênio me forneceu. Com efeito, somente cerca de um ano depois, ao cabo de minha segunda estadia em Caruaru (quando eu pude cotejar os primeiros depoimentos de Eugênio com as narrativas de seus familiares) é que pude situar os temas abordados por meu amigo no contexto da paisagem sócio-cultural do bairro do Salgado. Com o tempo, lendo minhas anotações de campo, me deparei com uma correspondência muito grande entre as primeiras formulações de Eugênio e as falas de seus irmãos e de seus pais, como de resto, de muitos outros moradores do bairro (costureiros, costureiras juntamente com seus familiares) com quem pude dialogar.

Nesse nosso primeiro contato meu interlocutor elaborou uma descrição mais ou menos genérica do universo das costureiras e dos costureiros de seu bairro na intenção de me apresentar, em linhas gerais, seu contexto social. Suas generalizações didáticas (cujo objetivo era precisamente me iniciar em seu mundo), entretanto, não deixaram de apresentar regularidades que têm perpassado os depoimentos de muitos de meus novos interlocutores, em Caruaru, mormente, as falas de sua própria família, mas também uma memória prática, incorporada nos "habitus" dos trabalhadores do bairro do Salgado. O que apresento aqui é apenas um resumo dos dados que Eugênio me forneceu no dia em que nos conhecemos, não constituindo, por conseguinte, um relato exaustivo de nossos primeiros diálogos.

Eugênio então principiou dizendo que fundamentalmente existem "duas realidades" que coexistem no pólo da sulanca. Por um lado - disse ele - unidades de produção familiar (fabricos) cujas famílias trabalham juntas. Frequentemente toda a família, ou a maior parte dela, encontra-se envolvida com a produção de roupas. Desta maneira, há casos nos quais não há salários fixos, mas um orçamento familiar coletivo

\footnotetext{
${ }^{5}$ Oliver Schwartz, no contexto dos operários mineiros do norte da França, também destaca o papel, por assim dizer, emancipador da bricolagem a partir da noção marxiana de "livre jogo das forças": "Lieu de reconstituiton des forces, aire garantie et reconstitutive de la 'présance' et de ses prestiges, le 'foyer' se rête ancore à d'autres investissements que nous apparaîtront progressivement dans la suíte de cette enquête. Il s'offre à l'appropriation et à la maîtrise, donc aussi à la poursuite de réalisations valorisantes aussi bien féminines que masculines : la maison, le jardin, l'intérieur choyé, les enfants constituent un miroir de l'oeuvre parentale. Il définit un espace d'auto-appartenance et de libre jeu des forces, qu'on voit $s$ ' 'éclater' dans toute une passion masculine du bricolage". (Schwartz, 1990: 95, grifo meu).
} 
amiúde gerido pelos pais ${ }^{6}$. Muitas destas unidades produtivas domésticas vendem por conta própria seus produtos na feira da sulanca.

Por outro lado, existem as facções, onde as peças são produzidas também em domicílio e fornecidas para uma empresa que, por seu turno, aplica apenas a etiqueta com a marca para, em seguida, comercializá-las. Um número minoritário destes fabricos é formalizado ${ }^{7}$, com registro de CNPJ, registro de operários em carteira profissional, etc. Outros ainda são registrados como pessoa física; neste caso as etiquetas das roupas trazem inscritas o CPF e o nome do fabricante ${ }^{8}$.

Em ambos os casos, nos deparamos também, segundo as palavras de Eugênio, com a presença eventual do trabalho infantil, freqüentemente ligada á limpeza, acabamento e embalagem dos produtos ${ }^{9}$. A experiência de professor da educação básica permite também a Eugênio elaborar uma avaliação sobre certas consequências possíveis do desenvolvimento econômico dos sulanqueiros no imaginário infantil. Desta maneira ele cita casos em que os filhos dos donos de fabricos formulam comentários do tipo: "para que estudar, professor? Se o meu pai não estudou e ganha mais do que você?" Na avaliação de Eugênio, os lucros decorrentes do trabalho físico podem concorrer, aos olhos de alguns alunos, para uma desvalorização do trabalho intelectual ${ }^{10}$.

Eugênio destaca também as ambiguidades presentes neste setor da economia caruaruense: se, por um lado, o trabalho na sulanca constitui uma possibilidade de vida

\footnotetext{
${ }^{6}$ Embora não necessariamente por eles.

${ }^{7}$ No ano de 2003, haviam 12 mil unidades produtivas na região do agreste, das quais apenas $8 \%$ delas eram formais. No conjunto estas empresas teriam um faturamento mensal superior a R\$144 milhões, empregando 76 mil pessoas e produzindo, em média, 57 milhões de peças de vestuário por mês. Fonte: UFPE (2003). Embora atualmente, sobretudo, em decorrência da predominância informalidade mesma, seja difícil acessar os números correspondentes, estima-se que estas cifras sejam bem maiores - como se disse, tangenciando a casa dos milhões.

${ }^{8}$ Esta modalidade de registro da produção de vestuário por conta própria, onde o fabricante aplica na peça uma etiqueta com seu nome e CPF, constitui um caso emblemático da complexidade de arranjos econômicos construídos por meus interlocutores no agreste pernambucano. Complexidade por vezes ofuscada pela dicotomia formal/informal.

${ }^{9}$ Apenas para ampliarmos ligeiramente o escopo das generalizações heurísticas deste artigo, saindo momentaneamente do âmbito da família em foco - embora não da esfera do bairro do Salgado e de suas relações de vizinhança e afinidade - evoco aqui uma entrevista que fiz com Diano, dono de um fabrico e fornecedor de facção para costureiros e costureiras domiciliares (a maioria dos quais são também seus parentes): "A limpeza eu pago menino. Pago $\mathrm{R} \$ 00,10$ por peça limpa. Aqui tem essa vantagem que a gente pode usar menino, em cidade grande você já não pode usar menino, né. Que a fiscalização é maior". ${ }^{10}$ Uma vez mais a família de Diano pode servir para ilustrar este ponto. Assim é que seu irmão mais novo, Enrique, que tem 12 anos de idade, faz exatamente a mesma leitura sobre a escolarização que Eugênio nos apresenta: "A maioria dos sulanqueiros ricos, se dá bem é trabalhando mesmo, ninguém estudou não. Estudar, fazer faculdade pra trabalhar pros outros eu não quero. O Enrique mesmo até ele já fala que o estudo atrapalha ele a ganhar dinheiro. Porque ele tem que fazer pouco aqui porque tá estudando. E ele queria ganhar mais né? Ele queria parar de estudar, a gente que não deixou". (Diano).
} 
para os trabalhadores frente ao desemprego no âmbito do "mercado de trabalho" 11 formal; por outro lado, há também casos de ex-trabalhadores que, com o tempo, se transformam em donos de grandes fabricos ou confecções. Neste caso é frequente que eles lancem mão de dispositivos de exploração similares àqueles a que já foram um dia submetidos.

Meu interlocutor cita ainda certos dispositivos empregados pelos patrões para driblar as leis trabalhistas. Por exemplo, a simulação de falência para não arcar com os encargos sociais. Menciona outrossim, articulado com isso, a incorporação de padrões consumistas exorbitantes por parte dos ex-trabalhadores que crescem como donos de fabricos - "o sujeito cresce economicamente, e compra um carrão, compra á vontade e depois pede falência para não pagar as indenizações dos trabalhadores”, comenta.

Sobre a origem deste aglomerado de fabricos e confecções de vestuário na região, Eugênio diz que, a partir das décadas de 1960 e 1970, houve um grande volume de migração para o Sudeste do país, sobretudo São Paulo. As próprias redes de comércio que se desenvolveram entre São Paulo e o Agreste pernambucano contribuíram para o desenvolvimento de fabricos que utilizavam, como matéria prima, os retalhos residuais das grandes indústrias têxteis da região Sudeste. Com o tempo, o crescimento do pólo da sulanca permitiu a muitas famílias imigrantes retornarem para sua terra natal ${ }^{12}$. Inicialmente, no caso de Santa Cruz do Capibaribe e de Caruaru, as mulheres eram as principais artesãs da sulanca. Ao longo do tempo, entretanto, os homens desempregados começaram a se inserir neste setor de trabalho. Isso não sem certo preconceito inicial por parte destes em relação ao ofício de costura historicamente um setor de mão de obra marcadamente feminina. Com o tempo, contudo, este preconceito foi sendo deslocado pela oportunidade formidável de trabalho que a costura na sulanca representava e, conseguintemente, os homens constituem hoje boa parte do contingente dos trabalhadores dos fabricos.

\footnotetext{
${ }^{11}$ Emprego aqui as aspas para sinalizar o fato de que a expressão "mercado de trabalho" é parte de um esquema nativo muito particular, bem expresso em uma determinada teoria econômica. José Sérgio Leite Lopes, conquanto no contexto específico das fábricas têxteis, é quem chama a atenção para o fato: "Conforme veremos mais adiante, a ação aliciadora da Fábrica Paulista constituiu-se num dos principais pontos de entrada de novos operários, recém-proletarizados, nesse campo de forças sociais regulando a entrada e saída de trabalhadores das fábricas têxteis a que se denomina correntemente com uma imprecisão eivada do etnocentrismo mercantil da teoria econômica tão combatido por Palanyi, de 'mercado de trabalho', embora restrito, das fábricas têxteis". (Leite Lopes, 1988: 40, grifo meu).

${ }^{12}$ Mais tarde Eugênio me contou que seus atuais interesses de pesquisa referem-se às questões ligadas à migração, sobretudo a chamada "migração de retorno" que vem ocorrendo vigorosamente na região do Agreste pernambucano. Este é o tema da monografia que ele está escrevendo para sua especialização em sociologia. Há também que se registrar que Eugênio, ele mesmo, passou pela experiência da migração de retorno, por ocasião de sua infância, ao cabo do período no qual toda a sua família viveu em São Paulo.
} 
Este pequeno resumo pretende ser um preâmbulo aos depoimentos que anseio relatar no que se segue. Trata-se de chamar a atenção para as ressonâncias dos temas abordados inicialmente por Eugênio nas formulações subsequentes de seus familiares. A seguir apresento trechos de um longo diálogo, permeado de ensinamentos sobre a costura e entremeados de lições acerca de outros ofícios, que entabulei com o pai de Eugênio, seu José Mário. Na segunda parte apresento um fragmento das memórias de sua mãe, dona Eugênia, referente aos primórdios do pólo de confecções do Agreste pernambucano. Juntos os depoimentos compõem, creio, um quadro expressivo de estratégias econômicas bastante frequentes entre as famílias do Salgado, bem como de certa "memória coletiva" (Halbwachs, op. cit.) elaborada a partir da experiência, a um só tempo, de residência e de trabalho, neste bairro. A este respeito, tudo parece se passar como se as declarações de Eugênio constituíssem a expressão de sua memória incorporada $^{13}$, produzida no interior de suas experiências na família e no bairro.

\section{A costura de vestuário e outros ofícios}

Quando, no dia 11 de maio de 2010, retornei, cerca de um ano depois de minha primeira viagem exploratória, a Caruaru, tive a feliz oportunidade de conhecer toda a notável família de Eugênio, meu primeiro colaborador em 2009, agora convertido em grande amigo. Todo o crédito pela iniciativa de conseguir uma casa para me receber, nas proximidades de sua própria residência - bem como das de seus familiares - deve-se a ele. Quando cheguei do Rio de Janeiro encontrava-se já tudo preparado para me acolher, fato que facilitou largamente minha vida, fornecendo as condições materiais necessárias para que eu pudesse retomar imediatamente a investigação ${ }^{14}$.

Ao chegar ao endereço que Eugênio me forneceu, por volta das 10h00min da manhã fui recebido por Mário, seu irmão. Mário é graduado em História pela FAFICA (Faculdade de Filosofia de Caruaru), tendo concluído também uma especialização na área; trabalha atualmente como professor substituto na mesma faculdade. Estávamos agora ambos sentados no banco de uma pequena pracinha que fica próxima ao conjunto

\footnotetext{
${ }^{13}$ Inspiro-me aqui em Rosalind Shaw, para quem o corpo constitui o lugar onde se situa a "memória pratica" (Shaw, op. cit: 7) sendo, por conseguinte, uma "entidade mnemônica" (ibidem p. 5, tradução minha do inglês).

${ }^{14}$ Roberto DaMatta faz referência a uma determinada fase da pesquisa etnográfica - por ocasião dos primeiros dias em campo - a que dá o nome de "período prático", "quando nossa preocupação muda subitamente das teorias mais universais para os problemas mais banalmente concretos" (DaMatta, 1978: 24), referidos, dentre outros aspectos, às condições materiais da pesquisa de campo, tais como conseguir comida, habitação, etc. No meu caso particular, tais problemas foram quase que totalmente resolvidos pela hospitalidade da família de dona Eugênia.
} 
de casas contíguas onde moram os pais, e cada um dos quatro filhos com suas respectivas esposas; e onde também passei então a residir por dois meses. Diante de nossos olhos erguiam-se dezenas de prédios recém construídos, a maioria ainda sem reboco encontrando-se, pois, apenas "nos tijolos" como se diz popularmente. Tratava-se do bairro do Salgado. Às nossas costas encontrava-se o Bairro Universitário, constituído de residências mais antigas, a maioria delas consideravelmente luxuosas, em contraste com aquelas diante de nós. Era uma tarde com tempo bastante agradável e eu contava a Mário minhas intenções de pesquisa. Ele então me disse:

\begin{abstract}
Hoje aqui nós nos deparamos com a seguinte realidade que você vê aí - um bairro que é considerado pobre, mas com diversas casas sendo ampliadas, com seus moradores comprando carros que antes somente o pessoal daqui de trás podia comprar (fazendo um sinal indicando o Bairro Universitário às nossas costas), carros zero, carrões do ano. E todo isso em decorrência da sulanca. Com homens e mulheres trabalhando na costura e propiciando um desenvolvimento econômico impressionante. E não só na costura, meu primo aqui (apontando para outro rapaz que participava de nossa conversa) é indiretamente sulanqueiro. Ele trabalha com instalação elétrica de uma confecção. Se a costura cair, ele também sai prejudicado. E assim acontece com todo mundo aqui. Se o trabalho na sulanca cai, prejudica o médico, o advogado, enfim, todos os outros segmentos da economia de Caruaru.
\end{abstract}

Estas palavras de Mário podem ser consideradas um prólogo ao relato que obtive três dias mais tarde, quando finalmente conheci seu pai. Por seu turno, seu José Mário, tendo sido informado de antemão acerca de meus interesses de pesquisa, tomou de um pequeno banquinho de madeira e me ofereceu para que eu pudesse sentar junto dele, na laje de sua casa, a fim de falar comigo sobre o tema. Sem interromper o trabalho que realizava no momento em que cheguei - a saber, a confecção artesanal de pequenas caixinhas de papelão, papel colorido e bambu -, ele então iniciou o que me pareceu, sem exagero, uma aula de "sociologia espontânea"15 (Bourdieu, 1963):

Veja você que este bairro aí da frente (apontando para a área residencial diante de nós) é o mais populoso de Caruaru. Tem 80 mil habitantes! A cada dez casas, oito são fabricos. Veja você, Toritama tem 23 mil habitantes, Santa Cruz do Capibaribe tem 70 mil habitantes, Surubim...

Meu interlocutor enumerou, com grande destreza, diversas cidades contíguas a Caruaru, fornecendo-me suas respectivas cifras populacionais.

\footnotetext{
${ }^{15}$ Esta aproximação entre as formulações de seu José Mário e a noção de uma "sociologia espontânea" me foi inspirada por um comentário do professor José Sergio Leite Lopes a quem aproveito para agradecer pelas constantes orientações sem, contudo, evadir-me de todas as responsabilidades pelos erros e problemas deste texto.
} 
Então veja, só o bairro do Salgado tem uma população maior que todas estas cidades e de algumas delas somadas entre si. E em dez casas, oito são fabricos. Só de lavanderia de jeans tem umas duzentas. Então o bairro do Salgado economicamente é o mais forte de Caruaru. É o que segura Caruaru e a feira da Sulanca. Se um candidato a prefeito criar problemas aqui ele perde as eleições.

Seu José Mário me expunha suas ideias com uma voz firme, formidável articulação e uma força que me dissuadia de duvidar de seus números. $\mathrm{O}$ argumento que ele formulara a partir de sua descrição do bairro do Salgado, fazia referência (conforme descobri ulteriormente) a um tema bastante recorrente nas falas dos demais interlocutores que conheci no local, bem ilustrado nas múltiplas variações da frase nativa: O Salgado é uma cidade dentro de outra. Dando sequência à sua exposição ele se pôs a fazer distinções entre os ofícios ligados à sulanca.

Aqui dentro (no bairro do Salgado) você tem lavanderias, fabricos e facções, que são coisas diferentes. Tem o cabra que trabalha na lavanderia, o dono do fabrico e os costureiros dos fabricos e têm os costureiros de facção, que trabalham em casa pros dono do fabrico. Tem facção que a pessoa trabalha em casa e o dono só pega e vende, só põe a mão na grana. Então tem estas três coisas diferentes pra você pesquisar - os fabricos, as lavanderias e as facções.

Entretanto, para além destas "três coisas diferentes", a fala de meu informante parecia me alertar para as variações no trabalho dos sulanqueiros e para a interpenetração de ofícios profissionais que coexistem com a costura e comercialização de vestuário, que caracteriza fundamentalmente a sulanca. Tratam-se daqueles múltiplos arranjos produtivos locais que são obliterados pela expressão Arranjo Produtivo Local de confecções (no singular e com maiúsculas) bastante empregada pelos ideólogos do empreendedorismo, representados, mormente pelos consultores ${ }^{16}$ do SEBRAE, SENAI e da ACIC (Associação Comercial e Industrial de Caruaru). Enquanto falava, meu informante seguia em seus procedimentos manuais de confecção de caixinhas de papelão com excepcional habilidade, de uma maneira notavelmente tranquila. Estas operações artesanais de meu interlocutor, contudo, não o impediam de selecionar as palavras também calmamente para me apresentar seus pontos de vista.

Os fabricos cresceram muito, visse? Mas cresceram sem nenhum apoio do governo. O desenvolvimento da sulanca é de responsabilidade do trabalhador, do esforço do povo mesmo. O governo só entrou num acordo, por baixo dos panos, de não apertar

\footnotetext{
${ }^{16}$ Estes consultores são também denunciados como os maiores defensores da privatização da feira da sulanca, segundo os trabalhadores sulanqueiros.
} 
a fiscalização. Mas foi o povo daqui, de Toritama e de Santa Cruz (do Capibaribe) que levantou a sulanca. Santa Cruz era chamada 'a cidade da fome'. E hoje você vai lá e tem um monte de mansão. Foi uma família de Santa Cruz que criou a sulanca. Eu não lembro mais o nome do cidadão, mas Eugênia sabe quem é. Ele era caminhoneiro e trouxe uns retalhos lá de São Paulo pra mulher dele costurar. Eram roupas de retalho que ela vendia em uma toalha estendida no chão. Que o sulanqueiro original não é aquele que vende em banco não, é o que vende no chão. O cabra vende no chão, depois compra um banco, depois compra uma loja e cresce e fica rico ${ }^{17}$. Veja você, tem pobre, rico e milionário, né? Dizem que a tendência do pobre é ficar rico e a tendência do rico é ficar milionário ${ }^{18}$, né? Mas eu inverto a coisa: se o milionário não se cuidar, ele desce pra rico; se o rico não se cuidar, ele desce e vira pobre e se o pobre descer mais ele vira miserável. Sempre que o de cima desce, o que está em baixo desce mais. Mas então Santa Cruz era chamada 'a cidade da fome' e hoje é a capital da sulanca. Lá, toda casa é um fabrico. Além disso, a sulanca cresceu num período que pegou um presidente de desenvolvimento pro Nordeste. O governo Lula foi um governo de muito desenvolvimento pros pobres ${ }^{19}$. E não só pros pobres, os banqueiros enriqueceram muito, eles não podem nem reclamar porque os juros estão altos, não tem inflação, foi uma beleza pros ricos também.

Deste modo, em que pese sua descrição da constituição e desenvolvimento do pólo da sulanca como um processo calcado na força e na agência dos trabalhadores, meu interlocutor não deixa de reconhecer a importância do contexto macro-social que, nos últimos anos, forneceu condições mais adequadas para o desenvolvimento do povo agrestino. E, no entanto, isso não significa reduzir a agência e a eficácia transformadora do trabalho deste povo. Continuou seu José Mário acerca da política.

\begin{abstract}
Agora, esse prefeito aí, esse tal de José Queiroz, como o antigo também o Toni Gel, é safado. A prefeitura mudou o local da feira da sulanca e começou a vender os bancos a quem paga mais. E vendia um banco pra três, quatro sulanqueiros com registro falso, só um registro com assinatura verdadeira. Então você veja que diante de um governo desse de Caruaru, a sulanca só se desenvolve por esforço do povo. Todo mundo tem uma máquina de costura em casa. Porque se a coisa ficar feia no serviço de profissão própria, o cabra corre pra costura ${ }^{20}$. Você veja o caso dos trabalhadores da construção civil. Aqui em Pernambuco, lá pras bandas do sertão, tem um pólo muito forte de gesso. Então eles estão agora empregando gesso pra construção civil. Tem o gesso lento, o gesso...
\end{abstract}

\footnotetext{
${ }^{17}$ É interessante observar as ressonâncias desta fala de seu José Mário com as denúncias formuladas por Eugênio que apresentei na introdução, referentes aos ex-sulanqueiros que se desenvolvem economicamente, transmutando-se em novos exploradores de costureiras e costureiros.

${ }^{18}$ Talvez esse "dizem" se refira a certo otimismo dos setores empresariais e comerciais, decorrente do intenso desenvolvimento econômico pelo qual atravessa contemporaneamente Caruaru, Santa Cruz do Capibaribe e Toritama como resultado da produção e comercialização da sulanca.

${ }^{19}$ A este respeito, Eugênio havia me contado que seu pai dizia que se Lula indicasse uma cachorra para concorrer à eleição presidencial ele votaria na cachorra e que o nordestino que não votasse no candidato indicado por Lula não era nordestino de verdade.

${ }^{20}$ Esta frase de seu José Mario demonstra que se os sulanqueiros (costureiras, costureiros e comerciantes de vestuário) tendem a lançar mão de outros ofícios profissionais para complementar sua economia doméstica, inversamente, os profissionais de outros ramos tendem também eles, por sua vez, a recorrer à costura e comercialização de roupas caso sua profissão não dê conta de fornecer boas condições materiais de existência para a família.
} 
Neste ponto seu José Mário elencou uma variedade de tipos de gesso que eu sou incapaz de reconstituir. Esta performance demonstrou seu vasto conhecimento no que se refere a uma infinidade de ofícios profissionais, como de resto a diversos aspectos práticos da vida, destacando-se aí suas estratégias econômicas. E não apenas os práticos, como atesta sua destreza matemática. "Então você veja esta parede aqui (apontando para a fachada de sua casa), pra um pedreiro fazer o reboco aqui ele vai levar de cinco dias a uma semana. Aí veja, essa parede deve ter uns..."

Meu interlocutor iniciou então um cálculo mental em voz alta. Estimou a área da parede em metros quadrados, multiplicou a razão pelo valor do trabalho do pedreiro acrescido do preço do material por metro quadrado e chegou ao resultado de $\mathrm{R} \$ 850,00$ para fazer o reboco da fachada da casa. Tudo isso com uma velocidade e destreza admirável. Por vezes, ao fazer o cálculo, sua voz lhe faltava como se o espírito tivesse se antecipado á fala, chegando, pois, ao resultado esperado antes que pudesse reconstituir oralmente as operações matemáticas executadas.

Agora veja, se você fizer a fachada com gesso, você gasta a metade do preço e faz em dois, três dias. Então o trabalhador da construção civil vai sendo deslocado. O pedreiro é ignorante feito um jumento, não se renova, não faz um curso ${ }^{21}$ e fica pra traz. Então, tem muita gente correndo pra costura na sulanca. Eu não, que minha especialidade sempre foi essa aqui (apontando pra uma peça de mármore) isso é mármore granito.

Perguntei então se ele faz o polimento da peça de mármore.

Hoje em dia não faço mais não porque a tecnologia se desenvolveu e hoje uma máquina computadorizada faz o polimento de setenta, oitenta metros quadrados de pedra a $100 \%$ de brilho. Enquanto isso, na máquina manual a gente faz dez metros quadrados a 50, 60\% de brilho. Então não vale a pena a gente competir com máquina computadorizada. Porque o gringo quer o mármore a $100 \%$ de brilho. Eles têm um sensor que você coloca sobre a peça e te fornece a porcentagem de brilho. Se a peça tiver abaixo de $98 \%$ de brilho, não serve pra exportação. Até $2 \%$ abaixo de $100 \%$ eles toleram, fora isso não. Então não vale mais a pena a gente competir com a máquina não né? Hoje em dia eu compro a peça já beneficiada e faço a modelagem. Mas é complicado visse? Antes eu trabalhava pra uma firma, mas aí é aquele negócio, né? Você sabe qual o único empregado que não quer ser patrão? É o guia do cego né? Que ele não quer ser o cego (risos). Então todo empregado quer ser

\footnotetext{
${ }^{21}$ De fato, sendo marmorista de ofício, seu José Mário passou em 2011 (depois de ter retomado os estudos interrompidos por ocasião da infância na $4^{\mathrm{a}}$ série do ensino fundamental) por um processo seletivo para o curso técnico de construção civil, que é oferecido pelo SENAI de Caruaru, tendo sido aprovado e iniciado o curso. Este curso, como muitos outros (notadamente aqueles ligados à área de moda e designer), foram implementados nas unidades do SENAI, do SESI, mas também do CEFET e da UFPE do município em decorrência do intenso desenvolvimento econômico acarretado pela sulanca.
} 
patrão e comigo não foi diferente ${ }^{22}$. Então eu pedi minhas contas e abri meu negócio. Mas aí é aquela coisa, o cabra sem instrução, sem capital de giro, é complicado né. Hoje em dia, pro cabra abrir um negócio deste ele tem que ter capital de giro e instrução; tem que ter uma noção de economia, de administração, etc. Senão é aquilo, o cabra vende esta caixinha aqui por dez reais aí ele acha que ganhou dez reais, vai lá e mete o pau no dinheiro, na cachaça e tudo. Mas ele tem que ver quanto foi o material, tem que tirar o salário dele, pra depois ver o que tem de lucro. Então tem o preço da caixinha, o valor dela que é o seu trabalho e o lucro. Mas quando o cabra abre o negócio e começa a vender isso não vem separado assim. Então, quando eu fui ver isso já foi agora pouco. Agora, a sulanca não, essa dá retorno, mas o cabra tem que trabalhar visse? Então tirando quem tá na agricultura, plantando coco ou criando boi, tá correndo todo mundo pra costura. Porque coco é igual boi, nada é desperdiçado. O boi até a merda dele, você me desculpe falar, o cabra aproveita né? Faz adubo. O coco é a mesma coisa, até a folha dele o cabra faz artesanato. E o coco dá três safras antes de você ter que fazer o replante.

Essa comparação entre a plantação de coco e a criação de gado bovino me pareceu paradigmática do habitus dos trabalhadores que conheci no agreste pernambucano - a saber, o habitus de aproveitar a maioria dos materiais disponíveis, transformando, por meio do trabalho, objetos aparentemente prescindíveis em produtos com valor de uso. O próprio termo nativo sulanca, como vimos, parece ser uma simplificação de "helanca do sul", segundo algumas versões; ou "sucata de helanca", segundo outras. Em ambas as versões trata-se de transmutar retalhos sem valor em peças de vestuário ${ }^{23}$. O reaproveitamento radical constitui, pois, uma prática cultural das mais difundidas localmente.

Um aspecto que me pareceu extremamente interessante e revelador: seu José Mário faz questão de sublinhar o protagonismo das mulheres no que se refere à construção de todo o pólo da sulanca. Protagonismo investido na iniciativa destas costureiras, mães e esposas de famílias empobrecidas pelas secas periódicas, de iniciar a costura de vestuário como possibilidade de produzir materialmente melhores condições de vida para suas famílias. Por outro lado, meu interlocutor registra imediatamente as

\footnotetext{
${ }^{22}$ Há que se registrar aqui que todo o conjunto de fabricos de vestuário da região parece ter se desenvolvido a partir de uma tendência dos trabalhadores do agreste a buscar "o trabalho por conta própria" (Brandão Lopes, 1964) em detrimento do trabalho assalariado - ou, em termos nativos, o trabalho para a família e com a família.

${ }^{23}$ De fato, este habitus do trabalho artesanal pode ser pensado em termos de memória incorporada das tradições locais. Tradições que deram origem, conforme veremos ulteriormente nas memórias de dona Eugênia, ao que se chama hoje de pólo de vestuário do agreste pernambucano. Uma das definições que Pierre Bourdieu dá de sua noção de habitus ilustra também o processo por meio do qual esta "história incorporada" pode produzir ação transformadora em meio a sua continuidade - do que o desenvolvimento da costura de vestuário como possibilidade concreta de produção da vida frente ás crises agrárias do agreste de Pernambuco constitui um exemplo: "The habitus - embodied history, internalized as second nature and so forgotten as history - is the active presence of the whole past of which it is the product. As such, it is what gives practices their relative autonomy with respect to external determinations of the immediate present. This autonomy is that of the past, enacted and acting, which, functioning as accumulated capital, produces history on the basis of history and so ensures the permanence in change that makes the individual agent a world within the world". (Bourdieu, 1990: 56).
} 
ambigüidades deste universo social, onde a baixa escolarização e o rápido acúmulo de dinheiro nas mãos de novos ricos não deixam de engendrar desigualdades e relações de dominação entre patrões (por vezes, ex-trabalhadores) e empregados.

\begin{abstract}
Agora, sobre os fabricos, se tem alguém pra ser endeusado (sic) nesta história toda são as mulheres. Foram elas que tomaram a iniciativa de começar a costurar. Isso a gente tem que dar o braço a torcer. Mas, hoje em dia, o problema que eu vejo da sulanca é que essa dinheirama toda tá na mão de ignorante, analfabeto. Então o cabra tem muito dinheiro e é ignorante, isso é um problema.
\end{abstract}

Vemos, pois, que seu José Mário, como de resto sua família, valoriza a escolarização formal como requisito importante para uma vida profissional bem sucedida. Mas sua fala sobre a "ignorância" e o "analfabetismo" dos sulanqueiros parece expressar um pouco mais - a escolarização aí parece figurar entre os requisitos necessários para saber lidar com "essa dinheirama toda" que decorre da sulanca. Dessa valorização da escola também dão prova seus comentários anteriores acerca da necessidade de conhecimentos de economia e administração para se abrir um negócio por conta própria. E, no entanto, sua valorização da educação formal não é por ele formulada em termos absolutos que seriam confrontados com uma ausência (também absoluta) de escolarização. Meu interlocutor faz antes distinções internas entre modalidades e níveis de ensino e conjectura acerca de seus respectivos valores no mercado de trabalho. Tanto assim que a certa altura de nossa conversa, ele me propõe uma questão difícil de responder, em uma típica inversão da relação pesquisador/pesquisado.

\begin{abstract}
Agora, você está aqui pesquisando, tá fazendo doutorado e tá nesse caminho aí. Eu te pergunto: qual a vantagem de você estudar tanto, de você estar seguindo este caminho - que meus filhos também estão; você só está um pouco mais adiantado, mas eles também parece que querem seguir este caminho - quando seria mais fácil você fazer um curso técnico que desse dinheiro? O Paulo (seu filho estudante de história), por exemplo, ele trabalha com gás. Se, no lugar de ele fazer a faculdade que ele está fazendo, ele fizesse um curso técnico na área de gás, ele entrava na Petrobrás ganhando 8,9 mil reais por mês.
\end{abstract}

Diante desta questão espinhosa, formulada por seu José Mário não pude fazer outra coisa a não ser parar e ficar em silêncio alguns instantes. "A pergunta é difícil de responder" - afirmei ${ }^{24}$. Por fim, lhe dei algumas respostas evasivas sobre "fazer o que se gosta de fazer", sobre "o caráter instigante da atividade científica e as condições de

\footnotetext{
${ }^{24}$ A questão parece ser tanto mais difícil por se coadunar com o que os ideólogos da administração de empresa chamam de tendências do mercado.
} 
estudo e pesquisa que uma carreira no magistério superior propicia" ou sobre "a posse de uma maior margem de liberdade de ação e de resistência quando se conhece algumas lógicas com as quais a sociedade opera", etc. Creio não tê-lo convencido muito.

Enquanto contava todas estas histórias - parábolas ilustrativas de seus pontos de vista e, mais que isso, de certa memória coletiva de sua família e, talvez em menor escala, de seus vizinhos - seu José Mário não parava de fazer, de uma maneira inalteradamente calma, suas caixinhas de papelão artesanais. Tratavam-se de cubos de papelão com cerca de 10 centímetros respectivamente na altura, largura e profundidade. Em todas as bordas ele colava palitos de bambu cortados longitudinalmente pelo meio e, por fim, recobria a superfície que permanecia exposta com um papel preto. Além das caixinhas cúbicas ele produzia também outras em formato cilíndrico ${ }^{25}$. A certa altura perguntei a ele qual era o propósito daquele trabalho e ele então convidou-me para entrar em sua casa. Na sala, encontrava-se dona Eugênia sentada no sofá, rodeada de arranjos de flores artificiais, de diversos tipos, que ela fazia nas caixinhas produzidas por seu marido. Ela então me convidou para sentar e começou a falar comigo.

Pois é moço, eu faço aqui esses arranjos de flores pra vender na feira. Comecei há pouco tempo porque cansei de trabalhar na costura, visse? Eu comecei muito cedo na costura, costurando desde os 13 anos. A pessoa ganha dinheiro, mas também trabalha muito. É o dia inteiro na máquina, ou então tendo que contratar gente para costurar, é muito cansativo. Você tem que se dedicar o dia todo. Então eu cansei. Agora eu faço esses arranjos de flores aqui vendo televisão. Isso aqui pra mim é uma terapia! Eu ainda tenho uns três bancos na feira da sulanca, mas agora só vendo mesmo. Não produzo mais não.

É com essa fala de dona Eugênia - tão expressiva de certa “desmedida do trabalho" (Cottereau, 1988) na costura de vestuário quanto reveladora de diversas outras possibilidades de vida investidas no habitus do trabalho artesanal - que passo a relatar rapidamente um fragmento de suas memórias.

\section{Memórias de família: o mito fundador da sulanca}

Foi a mãe de Eugênio quem me narrou uma das versões mais interessantes que ouvi sobre as origens do trabalho na costura, no Agreste pernambucano. Não haveria espaço aqui para reconstituir toda a sua narrativa, de modo que me contento a fornecer

\footnotetext{
${ }^{25}$ Aqui nos deparamos novamente com o que chamei de habitus ligado ao reaproveitamento de materiais aparentemente sem valor. Tais caixinhas são confeccionadas com os cilindros de papelão que servem como suporte para grandes rolos de jeans - tecido que serve como matéria prima principal para as peças de vestuário produzidas no bairro do Salgado.
} 
ao leitor um esboço bastante sumário. E, no entanto, mesmo uma mera indicação desta espécie de mito fundador do pólo de confecções do Agreste é suficiente para ilustrar certos temas recorrentes nas falas de meus interlocutores - temas dos quais este mito parece ser o principal articulador.

Segundo minha colaboradora, por volta de meados da década de 1970, havia em Santa Cruz do Capibaribe um comerciante dono de uma mercearia chamado Manuel Rufino. "Nesta época Santa Cruz era chamada 'a cidade da fome"” - afirmou dona Eugênia ratificando a fala de seu marido. "Era muita pobreza, sem condições de plantar, de trabalhar, uma tristeza só" - continuou minha interlocutora. Disse ainda que, por esta ocasião, dificilmente alguém comprava uma peça de roupa em algum comércio. As mães é quem costuravam as vestimentas da família, de maneira artesanal.

Mas, como a pobreza era muito grande, ninguém tinha dinheiro pra comprar cortes inteiros de tecido. De modo que, o vestuário local era confeccionado fundamentalmente com retalhos. Segundo dona Eugênia, seu Manuel Rufino ia sempre a São Paulo para comprar as mercadorias que vendia em sua mercearia. Vendo ele que os resíduos das grandes tecelagens de São Paulo, os retalhos, eram descartados passou a recolhê-los, levando-os para Santa Cruz do Capibaribe. Em chegando lá os despejou todos defronte à porta de seu comércio ${ }^{26}$. Por seu turno, as mães de família de Santa Cruz começaram a adquirir grandes pedaços desses retalhos (alguns dos quais eram suficientes para confeccionar um vestido inteiro, por exemplo) para empregá-los na costura artesanal de peças de roupa.

Esta matéria-prima, introduzida no município por Manuel Rufino, constituiu o insumo necessário para que algumas mulheres da cidade começassem a comercializar seus produtos artesanais, expondo-os sobre uma toalha estendida no chão ${ }^{27}$, nas ruas principais da cidade. Com o tempo, o volume de produção na costura e as vendas foram aumentando; de maneira que muitas famílias foram saindo da miséria em que antes se encontravam.

Ao encerrar sua narrativa sobre o papel desempenhado por Manuel Rufino na constituição histórica do pólo da sulanca, dona Eugênia arremata sua exposição

\footnotetext{
${ }^{26}$ Chamo a atenção aqui para as variações do que chamei de mito de origem da sulanca: Eugênio afirma que as redes de comércio de retalhos entre São Paulo e o Agreste Pernambucano é decorrência da migração; por seu turno, seu José Mario sugere (embora registrando que não se lembra ao certo) que os retalhos foram trazidos por um caminhoneiro; por fim, dona Eugênia nos apresenta a história de Manuel Rufino.

${ }^{27}$ Esta parte da história que me foi contada por dona Eugênia parece relacionar-se com a fala de seu marido mencionada: "Que o sulanqueiro original é aquele que vende no chão". (José Mário).
} 
desdobrando do episódio uma moral que constitui o próprio cerne de suas opiniões referentes ao valor e à força transformadora do trabalho. Opiniões estas parcialmente compartilhadas por muitos costureiros, costureiras e feirantes do bairro com quem pude conversar, mas, sobretudo, opiniões marcadas nas memórias da família de minha interlocutora.

Hoje em dia você vai em Santa Cruz só vê mansão. Uma cidade que era chamada 'a cidade da fome' e hoje não tem ninguém desempregado, tem um monte de 'barão'! E tudo começou com um homem que viu que tinha possibilidade de pegar aquele retalho, que não valia nada em São Paulo, mas que pro povo daqui, naquela época, tinha muito valor. Então uma pessoa só começou isso tudo. A gente só não muda esse mundo se não quiser. Eu acredito no trabalho!

Com efeito, a própria biografia de dona Eugênia - e também, de certa forma, a biografia coletiva de sua família, como de resto toda a história recente do bairro do Salgado - recapitula, em alguma medida, esta lógica segundo a qual o trabalho na sulanca transformou a paisagem sócio-econômica do agreste pernambucano. Conforme sua fala supracitada, minha colaboradora iniciou-se na arte da costura de vestuário aos 13 anos de idade. Por esta ocasião, arte $^{28}$ era efetivamente uma categoria aplicada às costureiras da região. Tratava-se de uma profissão de prestígio, qual seja, as costureiras de encarregação. A expressão nativa decorre do fato de que as classes mais abastadas financeiramente compravam belos cortes de tecido, levavam até as residências das costureiras e encarregavam-nas de confeccionar suas roupas - muitas vezes, modelos com acabamento refinado ${ }^{29}$ para festas e reuniões sociais ou solenidades.

Tendo aprendido inicialmente o ofício da costura com sua própria mãe, minha informante trabalhou primeiro em casa, como costureira de encarregação e, em seguida, empregou-se em uma camisaria da cidade. Segundo ela, mais tarde, em um curso de costura patrocinado pela igreja católica do qual ela foi aluna, o bispo da região, Dom Augusto Carvalho, passava horas aconselhando as aprendizes do curso a não trabalharem mais para os donos das camisarias. "Vocês estão sendo exploradas por eles"

\footnotetext{
28 "A arte é uma atividade produtiva que se liga à individualidade do agente, é uma posse sua. Pertence ao indivíduo que durante o processo de trabalho transforma o objeto de trabalho através da 'inteligência"'. (Alvin, 1983: 55). A produção de peças de vestuário, no Agreste pernambucano, neste período não se dava por "cooperação complexa" (ibidem: 56); o que caracterizaria "a perda da arte" porque "vários operários seriam encarregados da execução do mesmo produto" (Ibidem: 56). Também: "O fazer do artista ressalta o aspecto artesanal de seu trabalho, no sentido de ver sua obra acabada após ter percorrido ele próprio as etapas necessárias à sua realização". (Leite Lopes, 1976: 36).

${ }^{29}$ Muito do prestígio das costureiras de encarregação, neste período, decorria provavelmente de sua capacidade de agregar aos modelos de vestuário um valor, por assim dizer, estético; que pudesse ser apreciado pela "alta sociedade" como marca de seu "gosto refinado", indicadora, portanto, de sua “distinção social” (Bourdieu,1979).
} 
- dizia o bispo - "Façam como as mulheres de Santa Cruz, comprem retalhos e costurem em casa pra vender na feira" - continuava ele ${ }^{30}$.

De fato, dona Eugênia, inspirada pela transformação da vida de muitas mulheres, bem como de suas famílias, em Santa Cruz do Capibaribe - que, em decorrência da costura de vestuário em domicílio havia deixado de ser a "cidade da fome" - abandonou a camisaria e iniciou a produção por conta própria de roupas a serem comercializadas na feira de Caruaru. Semelhantemente à trajetória de dona Eugênia, segundo suas próprias palavras, para outras costureiras das camisarias de Caruaru a experiência da costura por conta própria deu muito certo libertando-as, por assim dizer, da exploração de seus antigos patrões.

Com o tempo, a gente foi percebendo que os donos das camisarias estavam enriquecendo e as costureiras estavam ficando pra trás. Aí, depois que a gente começou a costurar em casa pra vender na feira, eles perderam o monopólio, né? E muitos deles caíram tanto que tiveram que começar a vender do nosso lado na feira. Agora você veja, de patrões eles passaram a ter que vender lado a lado com a gente, em pé de igualdade. (dona Eugênia).

\section{Considerações finais}

Ao fim desta comunicação não ambiciono esboçar nenhuma conclusão senão apenas sublinhar alguns temas recorrentes nos múltiplos depoimentos de meus principais colaboradores, os quais me parecem estar registrados na memória coletiva da família de dona Eugênia.

Estes mesmos temas expressam também, em alguma medida, leituras de mundo compartilhadas por outras costureiras, costureiros, feirantes, familiares e vizinhos no bairro do Salgado. Principalmente, o que a família de dona Eugênia - detentora de formidável sensibilidade etnográfica, conforme tentei demonstrar aqui - verbaliza de modo mais consciente, por meio de seus depoimentos e narrativas mnemônicas, os demais trabalhadores do Salgado com os quais tenho convivido expressam nos habitus incorporados em suas práticas profissionais e sociais. $\mathrm{O}$ aspecto talvez mais saliente destes habitus consiste na interpenetração de múltiplos ofícios profissionais que coexistem com a costura e comercialização de vestuário, na região.

Seria possível, dos depoimentos de todos os familiares de dona Eugênia reproduzidos neste trabalho, identificarmos argumentações que destacam o valor

\footnotetext{
${ }^{30}$ Com efeito, também o historiador local, Josué Euzébio Ferreira, em uma entrevista a mim concedida, refere-se ao bispo Dom Augusto Carvalho, como um clérigo comprometido com as lutas cotidianas dos setores populares da sociedade.
} 
transformador do trabalho. Uma moral que decorre do fato de que a costura e venda de vestuário por conta própria eliminou parte expressiva da pobreza existente no agreste pernambucano, transformando um local árido em uma terra boa para se viver.

As falas de seu José Mário e de um de seus filhos, Mário, sugerem que todos os demais setores da economia caruaruense dependem, em maior ou menor medida, da sulanca - o que dá uma idéia da magnitude da transformação desencadeada pela costura de vestuário - e que mesmo trabalhadores de outros ofícios tendem a recorrer à costura quando seu próprio ramo não vai bem.

Esta pujança econômica dos aglomerados de fabricos e confecções do município confere certa proeminência também ao bairro do Salgado: "Então o bairro do Salgado economicamente é o mais forte de Caruaru. É o que segura Caruaru e a feira da Sulanca. Se um candidato a prefeito criar problemas aqui ele perde as eleições." (seu José Mário).

Por outro lado, as ambiguidades deste universo social ligado á costura e venda de vestuário não deixam de ser destacadas por meus informantes. A exploração patronal denunciada por Eugênio, em diversos momentos de nossos diálogos, encontra alguma ressonância em certos trechos das falas de seu José Mario, do que a nota 16 deste trabalho constitui apenas um exemplo.

Estes aspectos vistos negativamente pela família que me hospedou coexistem lado a lado com os benefícios da costura por conta própria destacados por todos os meus informantes. Tais benefícios como se disse são atribuídos, mormente ao trabalho transformador dos costureiros e costureiras da região. E, no entanto, em que pese o fato dos homens terem sido capazes de superar os preconceitos de gênero ligados ao trabalho na costura, deve-se reconhecer o mérito das mulheres ${ }^{31}$ pela iniciativa de iniciar o processo que deu origem ao pólo da sulanca. A este respeito a fala de seu José Mario é paradigmática: “Agora, sobre os fabricos, se tem alguém pra ser endeusado (sic) nesta história toda são as mulheres. Foram elas que tomaram a iniciativa de começar a costurar. Isso a gente tem que dar o braço a torcer”.

\footnotetext{
${ }^{31}$ Este aspecto da agência e do protagonismo das mulheres no campo econômico também foi registrado em Solo, cidade da região central de Java, segundo o relato de Suzanne April Brenner (1998), onde o trabalho feminino na produção e venda de Batik (setor têxtil) é o desencadeador da produção material e simbólica da riqueza local. Semelhantemente, no chamado pólo de confecções de roupas íntimas de Nova Friburgo, Rio de Janeiro, são as mulheres costureiras as responsáveis pela sustentação econômica do município e, mais do que isso, pela constituição de sua própria identidade como capital nacional da moda intima (Espírito Santo, 2009).
} 


\section{Referências}

ALVIM, Maria Rosilene Barbosa. "Artesanato, tradição e mudança social - um estudo a partir da 'arte do ouro' de Juazeiro do Norte". In: O artesão tradicional e seu papel na sociedade contemporânea. Textos de Berta G. Ribeiro e outros. Rio de Janeiro: FUNARTE/Instituto Nacional do Folclore, 1983.

BOURDIEU, Pierre. The logic of practice. Stanford: Stanford University press, 1990.

Minuit, 1979. La distinction: critique sociale du jugement. Paris: Éditions De Travail et travailleurs en Algérie. Paris-La Haye: Mouton, 1963.

BRENNER, Suzanne April. The domestication of desire: women, wealth, and modernity in Java. New Jersey: Princeton University press, 1998.

BRANDÃO LOPES, Juarez Rubens. Sociedade Industrial no Brasil. São Paulo: Difusão Européia do Livro, 1964.

COTTEREAU, Alain. "L'usure au travail: interrogations et refoulements". In : Le mouvement social. Les éditions ouvrières, 1988.

DA MATTA, Roberto. "O ofício do Etnólogo, ou como ter 'Anthropological Blues'". In: NUNES, Edson de Oliveira (org). A aventura sociológica: objetividade, paixão, improviso e método na pesquisa social. Rio de Janeiro: Zahar ed, 1978.

ESPÍRITO SANTO, Wecisley Ribeiro do. Trabalho, gênero e lingerie: tradição e transformação nas trajetórias das costureiras de roupas íntimas de Nova Friburgo-RJ. Dissertação de Mestrado. Rio de Janeiro: PPGAS/Museu Nacional/UFRJ, 2009.

HALBWACHS, Maurice. A Memória Coletiva. São Paulo: Vértice, 1990.

LEITE LOPES, José Sergio. A tecelagem dos conflitos de classe na "Cidade das Chaminés". São Paulo: Marco Zero Editora, 1988.

O vapor do diabo: o trabalho dos operários do açúcar. Rio de Janeiro:

Paz e Terra, 1976.

LÉVI-STRAUSS, Claude. O pensamento selvagem. São Paulo: Companhia Editora nacional, 1976.

NORA, Pierre. "Between Memory and History: les lieux de memoire". In: Representations, n. 26. Berkeley: University of California Press, 1989. p. 7-25.

SCHWARTZ, Oliver. Le monde prive des ouvrier: hommes et femmes du Nord. Paris: Quadrige/PUF, 1990.

SHAW, Rosalind. Memories of the slave trade: ritual and the historical imagination in Sierra Leone. In: Chicago and London: Chicago University Press, 2002.

UFPE. Estudo de Caracterização Econômica do Pólo de Confecções do Agreste de Pernambuco. Recife: Relatório final apresentado ao SEBRAE-PE, 2003.

WEBER, Florence. Le Travail à-côté: Étude d'ethnographie ouvrière. Paris: Ed. De l'École des hautes études em sciences sociales, 1989.

Recebido em: 30/04/2012

Aprovado em: 02/07/2012 